\title{
The Muslim Military Clergy of the Russian Empire at the End of the XVIIIth - Beginning of the XXth Century
}

\author{
Ramil R. Khayrutdinov ${ }^{1} \&$ Khalim M. Abdullin ${ }^{2}$ \\ ${ }^{1}$ Kazan (Volga Region) Federal University, Kazan, Russia \\ ${ }^{2}$ Institute of Archaeology named after A. Kh. Khalikov of Academy of Sciences of the Republic of Tatarstan, \\ Kazan, Russia \\ Correspondence: Ramil R. Khayrutdinov, Kazan (Volga Region) Federal University, 420008, Kazan, \\ Kremlyovskaya Street, 18, Russia. E-mail: ramilh64@mail.ru; Xalimabd@mail.ru
}

Received: June 15, 2015 Accepted: June 24, 2015 Online Published: June 30, 2015

doi:10.5539/jsd.v8n7p121 URL: http://dx.doi.org/10.5539/jsd.v8n7p121

\begin{abstract}
The urgency of the problem under investigation is primarily concerned with the significance of historical experience of interaction between a Muslim clergy and a military department of the Russian Empire for over a century and a half period of time. The article focuses on exploring the status and functioning of the institution of a Muslim clergy of the Russian Empire at the end of the eighteenth - beginning of the twentieth centuries. The leading technique to the study of this problem is based on a comprehensive overview of scientific literature and other sources of information. The authors observed the establishment and development of the regulatory framework for a Muslim military clergy. The structure, functions and powers of Muslim clerics in the military department are reviewed. The interaction of a Muslim clergy with certain troops and the military department in general is analyzed.
\end{abstract}

Keywords: the Russian Empire, Islam, Muslims, a military clergy

\section{Introduction}

The government policy toward religious minorities in the Russian Empire were noted for its complexity and heterogeneity. Accordingly, the same politics was implemented by the state institutions toward the ministers of the cult of religions that were recognized as tolerant in the empire (Zagidullin, 2006). One of the perspectives of these relations is the history of the interaction between the military department of Russia and the non-Orthodox clergy. This cooperation of a Muslim clergy and a military department became possible during the reign of Catherine II, mainly owing to the policy of the religious tolerance and the establishment of religious government control over Muslims (Azamatov, 1999).

The analysis of the fulfillment of religious needs of soldiers of different faiths is of particular importance in the context of the multi-confessional Russian Empire (Arapov, 2004).

Firstly, Muslim population of Russia had a dissimilar position toward the doing of military service: from the beginning of the eighteenth century Volga Tatars carried regular military service on equal bases with the common population of the country, Tatars and Bashkirs of the Ural and Siberian regions were involved in irregular forces, Crimean Tatars also provided a regiment from their midst, for many peoples of the Caucasus military service was of a voluntary nature, moreover, Central Asian Muslims were released from military service (Ishakov 2004). Consequently, the intensity of attracting Muslim clergy to perform the required rituals was varied depending on the regional component and the number of Muslims. All that makes it possible to identify the priorities for the religious policy of the autocracy in relation toward military men, and to explain the ways and methods of its implementation in a particular region.

Secondly, the soldiers' duty in the regular army and the navy, in the irregular forces and Cossack troops, in the establishments and institutions of the military department suggested various possibilities for the performance of religious needs of a Muslim military clergy (Nasyirov, 2005). The study of this issue makes it possible to reveal each of the general laws and concrete historical peculiarities of specific forms of Islamic worship in Tsarist Russia. 


\section{Methodological Framework}

\subsection{The Objectives of the Study}

It was fundamental to reveal the following issues in the research: to observe the regulatory and legal framework for a Muslim clergy in the military department; to examine the forms of activity and the social role of a Muslim clergy in the armed forces, divisions, establishments and institutions of a military department.

\subsection{Theoretical and Methodological Basis of the Research}

The methodological foundation of the research was based on a comprehensive approach of viewing different sources of information. In addition, a method of historicism and scientific objectivity was also implemented. The principle of historicism involves the study of the development of cooperation of a Muslim clergy and a military department in a certain historical period that was characterized by definite socio-economic, political, ideological and cultural conditions. The principle of scientific objectivity involves the analysis of this problem on the basis of the actual documentary sources that are not in contradiction with the objective reflection of reality.

\subsection{The Source Basis of the Research}

The framework of the research concludes the documents of the end of eighteenth - beginning of the nineteenth centuries, archival sources related to the functioning of troops, divisions, establishments and institutions of a military department, as well as central and regional government establishments responsible for religious policy. Moreover, certain foundation of the study was drawn from the published materials of the documentary character - regulations, memoirs and recollections, letters of soldiers, periodical press of that period.

\section{Results}

\subsection{The Formation and Development of the Legal Framework for the Activity of a Muslim Military Clergy}

During the first half of the eighteenth century in the Russian Empire there were attempts to unify the heterodox population of Russia in religious terms by enforcing them mainly through Christianization and by means of economic pressure on the unchristened. However, a foreign policy strategy toward Muslim regions bordering with the Russian Empire and a succession of actions taken by Muslims of the Volga and Ural regions, which were of religious and liberating character, make the supreme power to change the attitude to the problem of forced Christianization. Since the second half of the eighteenth century the shift to the interaction with a Muslim clergy is reflected in policies, that have brought more substantial results in the regulation of Muslims. Islam has been recognized as a tolerant religion of the Empire, as a result bringing the Muslim clergy to a foreign, religious service and documentation management in the southern borders of the empire. The executive authorities and the clergy were drifted together but at the same time, government establishments dictated the need for more precise control over its actions. Thus, the establishment of the Orenburg Mohammedan Spiritual Assembly, which was included into a general system of state bodies of Russia, and the appointment of Mufti, a senior religious body became possible(Zagidullin, 2006). Annexation of Crimean Khanate and Lithuanian land to Russia and equality to the nobility of the national elite of these territories allowed to integrate the higher strata of Muslims to the public service acting as military officers, forcing to reckon with the religious rights of the latter in the armed forces. Finally, all of these factors were reflected in the regulatory and legal acts, as well as the formation of numerous military units of the Muslims at the end of eighteenth century, led to the foundation of the Institute of Muslim clergy in the irregular troops at the turn of the centuries.

The ultimate development and evident improvement of the legal framework for activities of an authorized and public Muslim military clergy has occurred during the second period of the reign of Alexander I, and especially under Nicholay I. Hence, for the first time, it was allowed to perform spiritual duties in the regular army, in the military educational and military medical institutions, in the military plants (Salihov, Hayrutdinov, 2005), in the Navy religious rights to the arrested and convicted servicemen Muslims were guaranteed. During that period, Muslim clerics were officially elected and supported by the state in major provincial cities (Astrakhan, Kazan, St. Petersburg, Simbirsk, Orenburg, Ufa), in which the number of Muslim soldiers was significant. As it follows from the documents, the Muslim clergy on a regular basis were maintained in the military ports (Arkhangelsk, Astrakhan, Kronstadt, Revel, Sveaborg) in the Navy and in the navy hospitals in St. Petersburg and Sveaborg. On the one hand the admission of clerics to the military educational institutions, has allowed to preserve and educate in the bosom of Islam the Muslim society elite - the officers, who came mostly from the nobility, honored citizens and merchants, on the other hand, a privileged strata of Muslims was attracted to these establishments, that all was beneficial to the state. The whole range of the presented legal acts speaks for a certain level of tolerance in the military empire during that period (Arapov, 2004). However, some of the documents had revealed that Orthodox was the dominant religion in the empire, that possessed the exclusive right to conduct missionary work in the 
military department. Nevertheless, the forced Christianization typical for the Russian army in the eighteenth century, finally leaves the arena of history, bringing economic and ideological methods of missionary activity to the forefront.

The second half of the nineteenth century is characterized by the ambiguity of the regulative framework of the studied issue. Whereas the 60-70s of the nineteenth century were times of reform in all the vital spheres of the country, the 80-90s in the national historiography were considered to be the times of the counter-reform. This is mainly owing to the inconsistency of policy relating to the interaction of the Muslim clergy and the military department. At the same time, there was some consistency: the admission of the Muslim clergy into the staff of the irregular troops was continued, following the example of the orthodox military clergy, for the first time Muslim clerics were assigned to some regular troops and staffs on a standard basis. In the 1866 by the Decree on the abolition of the state support to the clergy of the Kazan Military District, the government had passed on a more rational from a material point of view form of worship for military personnel in areas with dense population of Muslims. Instead of their regular allowance authorized Muslim clerics were involved by the command for performing religious ceremonies for the lower rank soldiers. With the introduction of compulsory military service the number of Muslims from the Volga-Ural provinces significantly increased in the regular army and the navy, but the standard of recruitment of regular regiments and divisions made it impossible to establish the Institute of regimental mullahs at this period, as the number of Muslims in every military unit was only half of the personnel. At the same time, the mutual performance of religious needs by the lower rank soldiers was not forbidden, and was formally legalized in the 1877 (Azamatov, 2002). Furthermore, an increase of adherents of different faiths in the armed forces could be explained by a scope of legal acts in 70-80s in providing religious services in the military medical institutions. The capture of the North Caucasus and a special attitude toward a Muslim clergy in the region (their authorized position in courts and military educational establishments contrasted with their counterparts from the interior provinces of Russia) has indicated the concern of the government in their actions. Providing even positions in the Table of Ranks to the Caucasus Muslim clergy, suggests a long-term strategy in the tsarist final appointment and naturalization of the region and its population. Finally, the staff reduction of the Muslim clergy in some cities in the 90s led to the complete closure of the assigned personnel of the Muslim clergy in the regular army in the 1896, with the exception of the Navy, that was explained as the spending cuts in the military department, and the general conservative and protective policy of the period. As it is evident from the legal and regulatory sources, this does not mean a complete break of cooperation of the Muslim clergy and the military department. The authorized Muslim clergy remained in the navy, in the Muslim irregular forces, in the Cossack troops, in the national administration and military schools in the North Caucasus, involvement of the clergy into the army, institutions and establishments of the military department had continued. But the fact of the abolition of full-time Muslim clerics in the regular forces give a sore feeling on the Muslim Ummah of the Russian Empire.

Eventually, the abolition of the assigned Muslim clerics was recognized faulty. A civil clergy could not adequately provide religious service to the soldiers, that was evident during the Russian-Japanese War of the 1904-1905s, when the command was forced to appoint civil imams to the troops called up for active duty. The revolution of the 1905-1907s years had opened the debate and led to the issue of the law in the 1908, according to which the Muslim clergy had revived in regular military forces. Currently, it had a distinct geographical and organizational structure. In those districts where the military positions of the mullahs were not provided, the Institute of Public Muslim clerics was involved. The fact that authorized Muslim clerics were given equal rights with the Catholic and Lutheran ones, gave the evidence of the importance attached to a Muslim military clergy in the country. Over a million of Muslims of the empire were mobilized to the front in the First World War, the state of affairs required the appraisal of the number of assigned Muslim clerics in the armed forces, institutions and establishments of the military department, as a result, in addition apart from national irregular regiments assigned Muslim clerics came out in divisions, corps and armies, as well as in the headquarters of some new military districts (Ishakov 2004). The February events of the 1917 once again have raised acute national and religious problems to a higher level, that made possible to establish independent national religious organizations and their branches across the country, beyond the former imperial Mufti. These organizations have taken control over a Muslim clergy and a military department. The matter of nationalization (Islamization) of individual military units ever more has raised on the agenda. On the positive solution of this issue it is possible to build a hierarchy of Muslim clergy in the army. By the end of the 1917 this process seemed to be completed to a certain extent by copying the structure of the Orthodox millitary clergy (Gizzatullin, 2002). However, the policy toward the country's secular, atheistic state, proclaimed by the Bolsheviks at the beginning of the 1918, had prohibited the close collaboration between the clergy and the military department of the Soviet Russia.

The analysis of regulatory framework has shown that Muslim clerics who were in coordination with the military 
department of the Russian Empire, originally had no distinct spiritual duties proposed by the authorities, which were defined only as "for the performance of the spiritual needs" in the documents. Afterwards, the authorities had differentiated between professional duties of the clergy in various military structures, depending on the scope of each of them. By the beginning of the twentieth century the main responsibilities of the Muslim clergy in the largest division of the military department - the regular army and navy have been identified: the swearing-in, the performance of public worship and sermons, the performance of the funeral rite. In the other divisions, establishments and institutions of the military department the duties of the Muslim clergy were depended on the kind of their functions.

\subsection{The Interaction of a Muslim Clergy and a Military Department}

At the end of the eighteenth century the Muslim military clergy for the first time was being involved into the spiritual service in irregular troops on a regular basis. The duties of the Muslim clergy were depended on the status of a military unit whether it was a national regiment, a national irregular troop, the Cossack troop. In the national regiments Muslim clerics were appointed directly by the command and were included to the military units of the country, they received salaries, got food provision and other benefits depending on the status of a regiment, a squadron or a troop. In the national troops, they were elected by the soldiers and were confirmed posts by the military command, but in general, they had carried spiritual service, that was slightly differ from day to day duties of a civil clergy. Muslim clerics were included into the staff with all provision payments only in case of hostilities or leaving the service outside the military land, when irregular command was formed by means of the troop population (Abdullin, 2008).

Correspondingly, it was the same condition of the Muslim clergy in the Cossack troops, the difference was that Muslim clerics were joint into a regiment and, therefore, they received all the necessary payments from the treasury in case the number of Muslims were at least half of the irregular formation. Admission of a Muslim clergy into the irregular troops was dictated by the demand of performing religious rites for the military people, including compulsory ceremonies such as taking the oath, or the funeral of the deceased, and also to strengthen the faithfulness of soldiers. Hence, the emphasis was laid on the admission of appropriate personnel into the irregular troops, which determined the procedure of the appointment of clerics by the command (Zagidullin, 2006).

The same as in the irregular troops, in the permanent army and in the navy the forms of attracting Muslim clerics to meet the religious needs of soldiers were different. In most cases the clerics were elected from the soldiers, then they were tested in religious knowledge and later were approved their post by the military command. At the same time the Muslim clerics who were chosen from the soldiers in some cases were excluded from the ranks of the military group in accordance with a particular decree of the Emperor concerning the staff appointment, in others cases they remained in the military service. Non-regular representatives of the Muslim clergy who were elected from the soldiers were carrying military service on general grounds, although the command could only formally include a military Mullah in its list but in a lower rank.

Another common way of attracting a Muslim clergy to the regular army was in accordance with the decrees of the Emperor to admit civil clerics into the garrisons, headquarters and troops. In this case, they became assigned military mullahs. In the event of the abolition of their posts regular mullahs did not return to military service in the lower ranks, they were just dismissed from the posts. The third form of interaction of the Muslim chaplains and the permanent army was the establishment of the institution of public Muslim military clergy. In this situation, the civil imam took the responsibility to serve the religious needs of the soldiers off-duty and did not get a salary from a government (except for the swearing and funerals). It was called a social voluntary occupation of the imam. The experience of years-long service of a Muslim clergy in the structures of the regular troops of the Russian Empire shows a real necessity for such cooperation for all stakeholders, and especially for Muslim soldiers. Islamic clerics, particularly in regions distant from the compact residence of Muslims, were the only sources to meet cultural and religious needs of the lower rank soldiers of the regular army for many years cut off from their homes. At the same time inconsistent government policies toward the Muslim military clergy bared the evidence of unwillingness to deal with issues of spiritual rights of minority religious soldiers in the permanent army.

From the beginning of the nineteenth century the Muslim clergy dynamically cooperated with the military educational institutions. It was owed to mutual interests of both structures: the military department was interested in the education of Muslim allegiance, and the clergy and worshippers were concerned about the performance of religious services and maintenance in the bosom of Islam, one of the most influential class of Muslims. 
The establishment of authorized Muslim clergy in the factories of the artillery division of the military department was caused by a considerable number of military Muslims in these enterprises. The government had gone even to the state-owned construction and management of mosques, not only maintenance of religious leaders. It was possible merely by taking into account the laws of war and religious backgrounds of soldiers and stern necessity for fulfillment of religious "needs", regardless of religious affiliation of lower rank soldiers (Salihov \& Hayrutdinov, 2005).

The military department was guided by the same principles when admitting a Muslim clergy into the military medical institutions. Here, the main activity of clergymen was comforting of the wounded and funeral of the deceased. The latter in the non-secular government had to suggest itself only with the participation of the clergy from the faiths to which the deceased belonged. In the military courts and military prisons the main responsibilities of Muslim clerics were swearing defendants and witnesses, suspects exhortation, educational preaching and the funeral of prisoners, that also could not be carried out without the participation of the clergy.

The unstable situation in the Caucasus region in Russia had allowed the government to keep the military department there for many years. In the circumstance of the abolition of the Muslim theocratic state in the North Caucasus, military authorities still could not but take into account the influence of the clergy on the mountaineers. Therefore, having detached the Muslim clerics from the control of the province, the government has left them some judicial powers. As a result, the Institute of assigned qadis had come into service in the courts of military control in the Caucasus (Avksentev, 1984).

The summarized data shows as well as the differences of service rights of Muslim military clerics, and also uniting links, especially the fact that they had the right to get a salary or a remuneration from the government for their spiritual performances. However, service pay and allowances in most cases were quite haphazard and more or less consistently were assigned only to Muslim clerics in the military factories, military medical institutions and civil courts of military control in the Caucasus. The allowance of the assigned Muslim clergy in the army comes to a specific system only at the beginning of the twentieth century.

There was also no distinct arrangement to provide benefits and rights at service. None of the Muslim clerics was endowed with the rights and privileges to the extent as it was defined for the Orthodox clerics. Only at the beginning of the twentieth century authorized Muslim clergy in some military districts were entitled with all the rights granted to priests in the service of the Catholic and Lutheran confessions. At the same time all the Muslim clerics, involved in the military department, had the same rights that were granted to official civil Muslim clerics on the territory of the Russian Empire.

Apart from their straight duties, the clergymen serving the spiritual interests of the soldiers were engaged in forms of activities inherent to a civil parish clergy, such as conducting five daily prayers and the Friday holiday reading sermons, registers of births, naming of newborns, newlyweds nuptials. They also should provide training in literacy and the fundamentals of the faith to the lower rank soldiers and their children. The duties of ideological nature, in the spirit of devotion to the throne and loyalty oath were also imposed on the Muslim military clerics. The latter circumstance was compensated by social activities and benefits that Muslim clerics bring to the Muslim Ummah of the country. It is worth to note a broad network of Muslim cemeteries and mosques across the country, that were constructed largely due to the initiative and efforts of a Muslim military clergy. They occurred mainly in remote areas of compact settlement of Muslims, becoming the religious and cultural centers, not only for the military people but for a small part of the Muslim civil population in these regions. The contribution of the representatives of the authorized and the public military clergy was essential in the sphere of spiritual culture of Muslims. In the final period of the existence of the Institute of Muslim clergy, its representatives actively participated in social and political life of the country. Being clerical and influential members of the Muslim community, they have left an imprint on the physical and spiritual culture of the people confessing Islam.

\section{Discussions}

The historiographical analysis makes it possible to distinguish three unequal in length and content periods of the study of the issue: pre-October (the second half of the XIXth century - the year of the 1917), the Soviet (before the beginning of the 1990s) and post-Soviet(from the beginning of the 1990s).

A common peculiarity of historiography of a military clergy at all the presented periods was that the priority was given to the study of the experience of the Orthodox chaplains (Barsov, 1879; Nevzorov 1883; Laskeev, 1900; Kandidov, 1929, Kandidov, 1932; Vasilenko, 1933; Suglobov, 1969; Kovalskiy 1986; Hristolyubivoe voinstvo, 1997; Buganov 2002, Kotkov, 2004). The problem of the interaction of a military department with other "tolerant" religions of the Tsarist Russia remained in the shadow of the Orthodox-state relations or were not 
studied at all.

In the pre-revolutionary period the problem of cooperation of a Muslim clergy and a military department of the Russian Empire had not been a subject of a special study. However, the matter of fulfillment of religious "needs" of Muslim soldiers was noted by A.F. Rittikh, a well-known researcher of the ethnic composition in the tsarist army. He pointed to the common practice of interaction between a Muslim clergy and a military department before the military reforms of the 60-70 years of the nineteenth century, when the necessity for serious consideration of this issue in connection with the increase of the number of Muslims in the army has raised (Rittih, 1875). In the publication of the ethnographer A.P. Martyinov the objectives and activities of the Muslim military clerics in the garrison of Simbirsk were viewed (Martyinov, 1898). In general, references to the Muslim clergy in the structures of the military department during the mentioned period were mainly used for informational purposes (Hristolyubivoe voinstvo, 1891, 1894). After the February Revolution of the 1917 in some publications the view about demands of Muslim citizens of Russia in the formation of national military units and the assignment of the representatives of the Muslim clergy was expressed (Tamarin, 1917; Minnullin, 1994). However, no scientific analysis was carried out.

In the first decades of the Soviet Union on the crest of anti-religious propaganda a large number of works dedicated to the relations with the representatives of religious confessions with "the old regime" were published. Some of them allow us to have a certain idea about the activity of the Muslim clergy in the military department of Russia (Murtazin, 1927; Sagidullin, 1927; Matorin, 1929; Ishemgulov, 1930, Kandidov, 1931; Arsharuni, Gabidullin, 1931; Kasyimov, 1932; Klimovich, 1936). At the same time, all these publications were written in the spirit of the disclosure of "counter-revolutionary activities and pro-monarchy direction" of the Muslim clergy in the structures of the military department. In chronological terms, the activities of Muslim clerics were limited to the beginning of the twentieth century.

In the next decades the concern about this issue was markedly reduced. In a number of publications the existence of such cooperation with the emphasize on its negative role from an ideological point of view was viewed (Smirnov, 1954; Sidorov, 1961; Usmanov, 1964; Ishmuhametov 1974; Avksentev, 1984). The monograph written by N.V. Galushkina, which provides a number of interesting facts from the history of the Muslim clergy in the described military formations should be noted (Galushkin, 1961).

The post-Soviet period is characterized by the growing interest to the country's history, in particular to those of its problems, that for years could not be objectively considered due to ideological reasons. The problem of a military clergy was not an exception in this respect. During the mentioned period, a considerable number of works of a general nature is published, that is, in general, on the activities of the clergy of various denominations in the structures of the military department.

A considerable amount of sources related to the activities of the Muslim clergymen among the soldiers was included in the study dedicated to the history of residence of Muslims and Tatars in particular in various regions of Russia and abroad (Aminov, 1994, Grishin, 1995; Senyutkin, 1998; Iskandarov, 1999; Grishin, 2000; Hayretdinov, 2002; Faizrahmanov, 2002; Asadullin, 2004; Batyirgarey, 2004; Adutov, 2006; Tagirdzhanova, 2006; Kobzev, 2007). Certain information on the material culture of the Muslim peoples and the history of national military units in the Russian Empire are also observed (Usmanov, 1964; Podpryatov, 1997; Opryishko, 1999; Asfatullin, 2000; Volkov, 2001; Rahimov, 2002; Vakar, 2002; Gizzatullin, 2002 ; Nasyirov, 2005 and etc.).

A significant breakthrough in the research of the Institute of Muslim chaplains in the Russian Empire takes place at the turn of the XXth - XXIth century, when publications and monographs written by H.M. Abdullin, R.R. Khairetdinov, D.Ya. Arapov, I.K. Zagidullin, D.D. Azamatov, S.M. Iskhakov are come out (Abdullin, 2009; Abdullin 2013; Salihov, Hayretdinov, 2005; Arapov, 2004; Zagidullin, 2006; Azamatov, 1999; Azamatov, 2002; Ishakov, 2004), and etc.

\section{Conclusion}

The research conducted in accordance with its aims and objectives allows us to formulate the following conclusions.

The development of the state policy toward the Muslim clergy in the army, divisions, establishments and institutions of the military department has undergone several periods. Through the analysis of official sources the following periods may be distinguished: a) the end of the XVIIIth - beginning of the XIXth century - the foundation and development of the Institute of Muslim chaplains; b) the first half of the XIXth century - active involvement of the Muslim clergy to the military service in different troops, establishments and institutions of the military department, the establishment of legal and regulatory framework for their activities in these 
structures; c) the second half of the XIXth century - the year of 1896 - further reinforcement of the legal and regulatory framework, partly due to the military reforms; subsequent counter-reform, and, finally, the abolition of authorized Muslim clerics in the regular forces; d) beginning of the XXth century - regulation of the Muslim clergy in the military department before and after the well-known decree of the 1908 in relation to the revival of the assigned Muslim clergy in the military districts; the First World War and the legislative acts on Muslim chaplains.

The legal basis for the functioning of a Muslim clergy in the military department, which were developed as a result of a number of decrees at the end of the eighteenth century, got it complete and structured form only at the beginning of the twentieth century. At the same time during the nineteenth century there was a process of the regulatory framework formation for the activities of the Muslim clergy in the structures of the military department. The majority of regulations were mutually exclusive, inconsistent and even chaotic. At the same time in different types of troops, divisions, establishments and institutions various forms of cooperation with a Muslim clergy have been determined, while the Orthodox clergy in all structures of the military department was included on a regular basis and was governed by a single spiritual center and had a structured legislative and legal framework. Muslim chaplains was given its structured form only by the decree of the 1908. Thus, a spiritual hierarchy of the Muslim chaplains was formed, similar to the structure of the Orthodox military clergy. Although, as have already been mentioned, the institute of the church and the clergy in Islam historically did not exist, the government recognized Muslim clerics as a special clergy and built up relationships with them in such a manner. Merely, a similar viewpoint on the Muslim clergy allowed to integrate them into a spiritual empire-wide policies and build up relationships with government authorities, including the military department.

The dissimilarity in the interaction of Muslim clergy with diverse structures of the military department depended on the kind of the activity of the clergy in those or other troops, divisions, establishments and institutions. In the national regiments representatives of the Muslim clergy were appointed by the command and were included directly to the state military units. In the irregular national troops Muslim clerics were elected by the soldiers and were approved by the military command. But in general, they were carrying a spiritual service, that was slightly differ from day to day duties of a civil clergy. Muslim clerics were admitted to the staff only in case of hostilities or leaving the service outside the military land, when irregular command was formed from the troop's population. Similarly, it was the same condition of a Muslim clergy in the Cossack troops. The main difference was that in the case of formation of a regiment a Muslim cleric was included in its staff, only if the number of Muslims were at least half of an irregular regiment.

In the permanent army and in the navy the forms of admitting Muslim clerics were different. In most cases the clerics were elected from the soldiers, then they were tested in religious knowledge and later approved their posts by the military command. At the same time the Muslim clergy who was chosen from the soldiers in some cases were excluded from the ranks of a military troop, in others cases they remained in the military service. Another common way of attracting a Muslim clergy into the regular army and the navy was in accordance with the decrees of the Emperor on a civil clergy. In this case, they became assigned military mullahs. In the event of the abolition of their posts regular mullahs did not return to a military service in the lower ranks. The third form of the interaction between the Muslim clergy and the regular troops and the navy was in attracting the Muslim clergy as volunteers when a civil imam took the responsibility to serve the religious needs for the soldiers and did not receive a government compensation, except for a remuneration for swearing and funerals.

Even more a difficult undertaking was the involvement of Muslim clerics into spiritual activities in other divisions, establishments and institutions of the military department. First of all, Muslim clerics were involved in military schools and military factories. In the military educational institutions learning and religious activities of Muslim clerics could also have a full-time and part-time forms. The establishment of a Muslim clergy in the factories of the artillery division of the military department was caused by a considerable number of military Muslims in these enterprises and who worked on a regular basis. Involving of a Muslim clergy into the military medical institutions, military authorities followed the letter of the law stating that every soldier should be buried with full military honors and rites of the religion. In the military courts and military prisons the main responsibilities of Muslim clerics were: swearing the defendants and witnesses, suspects exhortation, educational preaching and the funeral of prisoners. All this in a unsecular government also could not do without the participation of the clergy of different faiths. Especially it is necessary to stipulate the activities of Muslim clerics in convoys of a military division in the North Caucasus. In the time of the abolition of the Muslim theocratic state, military authorities still could not but take into account the influence of the clergy on the mountaineers, therefore, when had dismissed the Muslim clerics from the management of the province, the government has left them some judicial powers. Hence, the Institute of assigned qadis came into existence in the 
courts of military control in the Caucasus.

In general, the forms of activity of Muslim clerics in various structures of the military department of the Russian Empire, as well as the state of affairs with clerics rights were clearly defined only by the beginning of twentieth century. The structure of the Muslim military chaplains was slightly differed from the government constructed hierarchy of a civil clergy. But the staff of these clerics were varied and included both representatives of the higher clergy and the lower worships of Islam. Accordingly, there were a variety of rights of an assigned clergy serving the religious needs of the soldiers. At the same time, the laws common to the Islam civil clergy were inherent to the military clergy from the moment of the spiritual "decree". Muslim clerics were placed on the staffing allowance only by analogy with the Orthodox chaplains, this fact indicates that at first they were not clearly defined by the authorities of the spiritual duties. Afterward, with the extension of cooperation between the Muslim clergy and the various troops, divisions, establishments and institutions, the authorities distinguished the professional duties of the clergy in various military structures, depending on the scope of each of them. The main responsibilities of the Muslim clergy in the largest division of the military department - the regular army and the navy - was the swearing of recruits, committing public prayers and uttering sermons, performing funeral rites "Dzhinaz." In other divisions, establishments and institutions of the military department the duties of the Muslim clergy were determined depending on the nature of each of them.

At the same time, except for officially given duties, the Muslim clergy in the military department was carried out the activity, which was inherent to the civil parish clergy. Frequently they did not focus entirely on official duties, but, being clerics and influential members of the Muslim military communities, they were engaged in a wide range of vital social affairs. Firstly, it is worth to note a widespread set-up of mosques and Muslim cemeteries across the country that were largely due to the initiative and efforts of Muslim chaplains. It should be emphasized that they occurred mainly in areas distant from the compact settlement of Muslims, and they became the religious and cultural centers not only for military people, but also for a small number of Muslim civil population in these regions. What's more the contribution of representatives of the public and authorized chaplains to the spiritual culture of the Muslim peoples was significant. In the last period of its existence the representatives of the Institute of Muslim chaplains actively participated in social and political life of the country. Thus, the Muslim military clergy has left its imprint in the material and spiritual culture of their people. At the same time we can not ignore the fact that under the autocratic government policy the duties of ideological character were also imposed on military mullahs and they were forced to defend the interests of the existing political system.

Thus, during the end of the XVIIIth - beginning of the XXth century the activities of the Muslim clergy was constantly in demand in the structures of the military department. In the context of unsecular government system the authorities could not ignore the necessity for the activity of representatives of the clergy of religious minorities, and have been forced to satisfy their religious "needs". Considering the multiethnic and multi-religious composition of the country, Russia's governors and leaders of its executive bodies lined up different relationships with ethnic and spiritual elite of the peoples living there. The same conditions were with the admission of the clergy of various confessions into the military department. Depending on political suitability and the practical necessity the military authorities were granted the right or left for years without attention on the interests of various confessions whose members served in the structures of the military department.

In general, the summarized data shows the challenge for further consideration and a more detailed investigation of activities of Muslim chaplains in Tsarist Russia. It is necessary to establish the identity of every Muslim clerics who interacted with the military department. A more detailed study of the activities of a clergy in these divisions, establishments and institutions should be held. The research also has revealed the necessity for a more careful study of the role of all the people of Russia in a selfless service to the Motherland.

\section{Recommendations}

The practical value of the research is that its findings and conclusions may be used in the preparation of the summarizing monographs on the military history of the Russian Empire and the history of the Muslim clergy in Russia, in the teaching practice of universities in delivering lectures and practical classes, in creating special courses on the history of military units, Indigenous people of Russia, the history of military institutions and establishments.

\section{Acknowledgments}

This work was funded by the subsidy allocated to Kazan Federal University for the state assignment in the sphere of scientific activities 


\section{References}

Abdullin, H. M. (2009). Musulmane i musulmanskoe duhovenstvo v voennom vedomstve Rossiyskoy imperii: sbornik zakonodatelnyih aktov, normativno-pravovyih dokumentov i materialov. Kazan.

Abdullin, H. M. (2013). Tataryi v rossiyskoy armii. Istoriya tatar s drevneyshih vremen v semi tomah. (Tom VII, s.194-198). Kazan.

Adutov, R. M. (2006). Tataro-bashkirskaya emigratsiya v Yaponii. Naberezhnyie Chelnyi.

Aminov, D. A. (1994). Tataryi v St. Peterburge. Istoricheskiy ocherk. Sankt-Peterburg.

Arapov, D. Yu. (2004). Sistema gosudarstvennogo regulirovaniya islama v Rossiyskoy imperii (pervaya tret XVIII - nachalo XX vekov). Moskva.

Arsharuni, A. M., \& Gabidullin, H. (1931). Ocherki panislamizma i pantyurkizma v Rossii. Moskva.

Asadullin, F. A. (2004). Moskva musulmanskaya: istoriya i sovremennost. Ocherki. Moskva.

Asfatullin, S. G. (2000). Severnyie amuryi v Otechestvennoy voyne 1812 goda. Ufa.

Avksentev, A. A. (1984). Islam na Severnom Kavkaze. Stavropol.

Azamatov, D. D. (1999). Orenburgskoe magometanskoe duhovnoe sobranie v kontse XVIII - XIX vekah. Ufa.

Barsov, T. V. (1879). Ob upravlenii russkim voennyim duhovenstvom. Sankt-Peterburg.

Batyirgarey, F. (2004). Tataryi v Tverskom krae (Istoriko-etnograficheskiy ocherk). Tver.

Buganov, A. V. (2002). Pravoslavie v russkoy armii XIX - nachalo XX vekov. Pravoslavnaya vera i traditsii blagochestiya u russkih v XVIII-XX vekah. (s. 140-155). Moskva.

Fayzrahmanov, G. L. (2002). Istoriya sibirskih tatar (s drevneyshih vremen do nachala XX veka). Kazan.

Galushkin, N. V. (1961). Sobstvennyiy Ego Imperatorskogo Velichestva Konvoy. San-Frantsisko.

Gizzatullin, I. G. (2002). Musulmanskie voennyie organizatsii (1917-1921 godyi). Kazan.

Grishin, Ya. Ya. (1995). Polsko-litovskie tataryi (Nasledniki Zolotoy Ordyi). Kazan.

Grishin, Ya. Ya. (2000). Polsko-litovskie tataryi: vzglyad cherez veka. Istoricheskie ocherki. Kazan.

Hayretdinov, D. Z. (2002). Musulmanskaya obschina Moskvyi v XIV-nachale XX vekov. Nizhniy Novgorod.

Hristolyubivoe voinstvo: pravoslavnaya traditsiya russkoy armii. (1997). Moskva.

Ishakov, S. M. (2004). Rossiyskie musulmane i revolyutsiya (vesna 1917 g. - leto 1918 g.). Moskva.

Ishemgulov, B. (1930). Uryis samoderzhaviese hem meselman diniya nezarete. Moskva. (na tat. yaz)

Ishmuhametov, Z. A. (1979). Sotsialnaya rol i evolyutsiya islama v Tatarii (Istoricheskie ocherki). Kazan.

Iskandarov, R. Sh. (1999). Verhnie i Nizhnie Chebenki. Sakmara.

Kandidov, B. P. (1929). Tserkovnyiy front v godyi voynyi. Moskva.

Kandidov, B. P. (1931). Tserkov i grazhdanskaya voyna na Yuge. Moskva.

Kandidov, B. P. (1932). Yaponskaya interventsiya i tserkov. Moskva.

Kasyimov, G. (1932). Ocherki po religioznomu i antireligioznomu dvizheniyu sredi tatar do i posle revolyutsii. Kazan.

Klimovich, L. (1936). Islam v tsarskoy Rossii. Ocherki. Moskva.

Kobzev, A. V. (2007). Islamskaya obschina Simbirskoy gubernii vo vtoroy polovine XIX - nachale XX vv. Nizhniy Novgorod.

Kotkov, V. M. (2004). Voennoe duhovenstvo Rossii: stranitsyi istorii. Sankt-Peterburg.

Kovalskiy, N. A. (1986). Imperializm. Religiya. Tserkov. Moskva.

Laskeev, F. M. (1900). Istoricheskaya zapiska ob upravlenii Voennyim i Morskim Duhovenstvom za minuvshee stoletie (1800-1900). Sankt-Peterburg.

Martyinov, P. (1898). Gorod Simbirsk za 250 let ego suschestvovaniya. Simbirsk.

Matorin, N. (1929). Religiya u narodov Volzhsko-Kamskogo kraya prezhde i teper. Moskva.

Minnullin, Zh. (1994). Tatar polklaryi ni ochen kirek?. Miras, 4. (na tat. yaz.) 
Murtazin, M. L. (1927). Bashkiriya i bashkirskie voyska v grazhdanskuyu voynu. Leningrad.

Nasyirov, I. (2005). Islam i voennaya sluzhba v Rossii. Islam, 1.

Nevzorov, N. (1883). Upravlenie duhovenstvom voennogo duhovenstva v Rossii. Sankt-Peterburg.

Opryishko, O. L. (1999). Kavkazskaya konnaya diviziya. 1914-1917: Vozvraschenie iz zabveniya. Nalchik.

Podpryatov, N. V. (1997). Natsionalnyie menshinstva v borbe za «chest, dostoinstvo, tselostnost Rossii...». Voenno-istoricheskiy zhurnal, 1997.

Rahimov, R. N. (2002). Doblestnyie syinyi Urala v Otechestvennoy voyne 1812 goda. Voenno-istoricheskiy zhurnal, 9.

Rittih, A. F. (1875). Plemennoy sostav kontingentov russkoy armii i muzhskogo naseleniya Evropeyskoy Rossii. Sankt-Peterburg.

Sagidullin, M. (1927). Tatarskie trudyaschiesya na putyah Velikogo Oktyabrya. Kazan.

Salihov, R. R., \& Hayrutdinov, R. R. (2005). Istoricheskie mecheti Kazani. Kazan.

Senyutkin, S. B. (1998). Istoriya islamskih obschin Nizhegorodskoy oblasti. Nizhniy Novgorod.

Sidorov, D. I. (1961). Voyna i religiya. Moskva.

Smirnov, N. A. (1954). Ocherki istorii izucheniya islama v SSSR. Moskva.

Suglobov, G. A. (1969). Soyuz kresta i mecha (Tserkov i voyna). Moskva.

Tagirdzhanova, A. (2006). Tataryi v Finlyandii. Vzglyad iz Sankt-Peterburga. Tatarskie novosti, 12.

Tamarin, A. (1917). Musulmane na Rusi. Moskva.

Usmanov, A. N. (1964). Bashkirskiy narod v Otechestvennoy voyne 1812 goda. Ufa.

Vakar, S. V. (2002). Russkaya imperatorskaya kavaleriya. Voenno-istoricheskiy zhurnal, 6.

Vasilenko, V. O. (1933). Ofitseryi v ryasah. Moskva.

Voennoe duhovenstvo. (1891, 1894). Entsiklopedicheskiy slovar F.A. Brokgauz, I.A. Efron. (Tom III., s.232; Tom VIa., s.846). Sankt-Peterburg.

Volkov, S. V. (2001). «Vostochnyie chasti» rossiyskoy armii. Vostochnaya kollektsiya, 3.

Zagidullin, I. K. (2006). Musulmanskoe bogosluzhenie v uchrezhdeniyah Rossiyskoy imperii (Evropeyskaya chast Rossii i Sibir). Kazan.

\section{Copyrights}

Copyright for this article is retained by the author(s), with first publication rights granted to the journal.

This is an open-access article distributed under the terms and conditions of the Creative Commons Attribution license (http://creativecommons.org/licenses/by/3.0/). 